\title{
Peningkatan Hasil Belajar Muatan IPA Peserta Didik pada Tema Peduli terhadap Makhluk Hidup Melalui Model Cooperative Learning Tipe CIRC di Kelas IV SDN 216/X Kuala Dendang Semester Ganjil Tahun Ajaran 2021/2022
}

\author{
Murbiatun \\ SDN 216/X Kuala Dendang \\ Jl. Kuala Dendang, Dendang, Kabupaten Tanjung Jabung Timur, Jambi \\ Murbiatun_@gmail.com
}

\begin{abstract}
This study aims to describe and obtain information on improving learning outcomes for the CIRC Type Cooperative Learning Model. This research is classroom action research which consists of two cycles, each cycle consists of two meetings. Each meeting consists of four stages, namely planning, implementation, observation, and reflection. The subjects of this study were students of class IV SDN 216/X Kuala Dendang, totaling 8 people. This research was conducted in the odd semester of the 2021/2022 academic year. Data collection techniques using tests, observations, and documentation. Data were analyzed using percentages. The results showed that through the CIRC Type Cooperative Learning Model, it could improve the learning outcomes of the fourth's grade students of SDN 216/X Kuala Dendang science content by replacing group members.
\end{abstract}

Keywords: Science learning outcomes, CIRC

\begin{abstract}
Abstrak
Penelitian ini bertujuan untuk mendeskripsikan dan mendapatkan informasi peningkatan hasil belajar muatan IPA Model Cooperative Learning Tipe CIRC. Penelitian ini merupakan penelitian tindakan kelas yang terdiri dari dua siklus masing-masing siklus terdiri dari dua kali pertemuan. Masing-masing petemuan terdiri dari empat tahapan yaitu perencanaan, pelaksanaan, observasi dan refleksi. Subjek penelitian ini adalah peserta didik kelas IV SDN 216/X Kuala Dendang yang berjumlah 8 orang. Penelitian ini dilaksanakan pada semeseter ganjil tahun ajaran 2021/2022. Teknik pengumpulan data menggunakan tes, observasi, dan dokumentasi. Data dianalisis menggunakan persentase. Hasil penelitian menunjukkan bahwa melalui Model Cooperative Learning Tipe CIRC dapat meningkatkan hasil belajar muatan IPA peserta didik kelas IV SDN 216/X Kuala Dendang dengan tindakan penggantian anggota kelompok.
\end{abstract}

Kata kunci: Hasil belajar IPA, CIRC

Copyright (c) 2022 Murbiatun

Corresponding author: Murbiatun

Email Address: murbiatun_@gmail.com (Jl. Kuala Dendang, Kabupaten Tanjung Jabung Timur, Jambi)

Received 10 January 2022, Accepted 16 January 2022, Published 16 Februari 2022

\section{PENDAHULUAN}

Pendidikan adalah pembelajaran pengetahuan, keterampilan, dan kebiasaan sekelompok orang yang diturunkan dari satu generasi ke generasi berikutnya melalui pengajaran, pelatihan, atau penelitian. Pendidikan sering terjadi i bawah bimbingan orang lain, tetapi juga memungkinkan secara otodidak. Kata pendidikan itu sendiri berasal dari bahasa Latin yaitu ducare, berarti "menuntun, mengarahkan, atau memimpin" dan awalan e, berarti "keluar". Jadi, pendidikan berarti kegiatan "menuntun ke luar". Setiap pengalaman yang memiliki efek formatif pada cara orang berpikir, merasa, atau tindakan dapat dianggap pendidikan. Pendidikan umumnya dibagi menjadi tahap seperti prasekolah, sekolah dasar, sekolah menengah dan kemudian perguruan tinggi, universitas atau magang. 
Peningkatan Hasil Belajar Muatan IPA Peserta Didik pada Tema Peduli terhadap Makhluk Hidup Melalui Model Cooperative Learning Tipe CIRC di Kelas IV SDN 216/X Kuala Dendang Semester Ganjil Tahun Ajaran 2021/2022, Murbiatun

Pendidikan dalam Undang- undang Nomor 20 Tahun 2003 Bab 1 Pasal 1 merupakan usaha sadar dan terencana untuk mewujudkan suasana belajar dan proses pembelajaran agar peserta didik secara aktif mengembangkan potensi dirinya untuk memiliki kekuatan spiritual keagamaan, pengendalian diri, kepribadian, kecerdasan, akhlak mulia, serta keterampilan yang diperlukan dirinya, masyarakat, bangsa dan negara. Dengan demikian, untuk meningkatkan mutu pendidikan perlu dilakukan berbagai inovasi. Pendidikan bertujuan untuk menjadikan anak mampu memainkan peran sebagai makhluk individu dan makhluk sosial sesuai dengan potensi yang dimilikinya. Peningkatan kualitas anak ini tidak hanya menjadi tanggung jawab pemerintah saja tetapi juga tanggung jawab orang tua, guru dan lingkungan masyarakat. Berdasarkan hasil belajar dan masalah belajar yang terjadi di Indonesia, maka akan dibahas mengenai mata pelajaran IPA di Sekolah Dasar. Sebelum membahas masalah yang terjadi pada peserta didik tentang masalah belajar-megajar pada mata pelajara IPA, yaitu akan membhas bagaimana mata pelajaran IPA itu sendiri

Melalui pengamatan kasat mata terhadap segala sesuatu yang berada di sekitar kita, maka kita akan menemukan bahwa bumi tempat kita hidup atau alam semesta ini ternyata penuh dengan fenomena-fenomena yang menakjubkan, penuh dengan keragaman yang memukau, yang kesemuanya itu menimbulkan pertanyaan-pertanyaan kepada kita tentang mengapa dan bagaimana semua itu dapat terjadi. Sejumlah penelitian mengungkapkan bahwa pemahaman seorang guru tentang hakikat sains berpengaruh terhadap bagaimana dia membelajarkan sains. Seorang guru yang memahami bahwa sains merupakan kumpulan ilmu dan pengetahuan cenderung menyampaikan sebanyak mungkin informasi kepada peserta didiknya. hal ini tentu tidak tepat sebab sains bukan hanya sekumpulan ilmu dan pengetahuan. Dalam perkembangan selanjutnya "natural sciences" sering disingkat menjadi science saja. Karena itu kata science selanjutnya digunakan untuk ilmu-ilmu alamiah. Dalam bahasa Indonesia kata "science" kemudian diindonesiakan menjadi "sains". Karena itu kita mengenal kata "sains", "sains dan teknologi", dsb.

Ilmu Pengetahuan Alam (selanjutnya disebut IPA) merupakan suatu ilmu yang menawarkan cara-cara kepada kita untuk dapat menjawab pertanyaan-pertanyaan itu, IPA pun menawarkan cara kepada kita untuk dapat memahami kejadian, fenomena, dan keragaman yang terdapat di alam semesta, dan yang paling penting adalah IPA juga memberikan pemahaman kepada kita bagaimana caranya agar kita dapat hidup dengan cara menyesuaikan diri terhadap hal-hal tersebut. Upaya Peningkatan Pembelajaran muatan IPA Maka dengan hal itu adapun upaya yang dapat dilakukan dalam upaya meigkatkan pembelajaran muatan IPA Pada Sekolah Dasar, antara lain yai Sebagai seorang guru, dalam menciptakan pembelajaran muatan IPA yang lebih sesuai dan mudah diterima peserta didik, sebaiknya menggunakan media berupa benda-benda konkret sebagai media pembelajaran. Guru hendaknya lebih aktif memberi dan menemukan ide-ide baru dalam memilih model pembelajaran yang tepat, sehingga peserta didik mudah memahami konsep yang dipelajari. Sekolah hendaknya menyediakan sarana dan prasarana pembelajaran yang relevan guna menunjang 
upaya peningkatan pembelajaran yang efektif dan menyenangkan. Selama proses pembelajaran sebaiknya guru lebih mementingkan aspek kompetensi dari pada aspek hafalan/ ingatan, karena kompetensi lebih tahan lama dan berguna bagi kehidupan peserta didik dimasa yang akan datang.

Kenyataan yang terjadi rendahnya hasil belajar mata pelajaran IPA di Sekolah Dasar adalah peserta didik kurang aktif dalam proses pembelajaran muatan IPA, saat guru memberikan kesempatan kepada peserta didik untuk bertanya dan memberikan pendapat, tidak satupun peserta didik yang berani berbicara. Program tuntas yang di harapkan oleh guru masih belum tercapai, di tandai dengan hasil belajar muatan IPA yang banyak mendapatkan nilai di bawah batas tuntas yang telah di tentukan sekolah yaitu 70. Berdasarkan hasil observasi terlihat hanya 2 peserta didik yang mencapai tuntas atau mencapai batas KKM atau sebesar 25\%. Selebihnya 6 orang lagi atau $75 \%$ tidak tuntas dalam belajar. Hal tersebut menandakan kurangnya motivasi belajar peserta didik yang membuat rendahnya hasil belajar peserta didik. Selain itu juga kurangnya pemanfaatan sumber belajar sehingga penanaman konsep IPA masih rendah dan peserta didik hanya berinajinasi tanpa adanya praktek yang nyata.

Salah satu upaya pemecahannya adalah menggunakan model pembelajaran kooperatif tipe CIRC yaitu Model pembelajaran Cooperative Integrated Reading and Composition-CIRC (Kooperatif TerpaduMembaca dan Menulis). Kelebihan Model Pembelajaran CIRCKelebihan dari model pembelajaran terpadu atau (CIRC) yaitu pengalaman dan kegiatan belajar anak didik akan selalu relevan dengan tingkat perkembangan anak. Kegiatan yang dipilih sesuai dengan dan bertolak dari minat peserta didik dan kebutuhan anak; seluruh kegiatan belajar lebih bermakna bagi anak didik sehingga hasil belajar anak didik akan dapat bertahan lebih.

\section{METODE}

Jenis penelitian ini adalah penelitian tindakan kelas. Penelitian ini dilaksanakan di SDN 216/X Kuala Dendang pada semester ganjil tahun ajaran 2021/2022. Subjek dalam penelitian ini adalah siswa IV dengan jumlah peserta didik 8 orang. Prosedur penelitian ini meliputi perencanaan, pelaksanaan, pengamatan, dan refleksi. Penelitian ini dilaksanakan dalam dua siklus, masing-masing siklus terdiri dari dua kali pertemuan. Teknik yang digunakan dalam pengumpulan data adalah observasi, tes, catatan lapangan dan dokumentasi. Data dianalisis melalui persentase dan reduksi data.

\section{HASIL DAN DISKUSI}

\section{Siklus I}

\section{Perencanaan}

Pada tahap ini peneliti mempersiapkan perangkat pembelajaran yang terdiri dari rencana pelajaran 1, LKS 1, bahan ajar, soal tes formatif 1, lembaran observasi dan alat-alat pengajaran yang mendukung. 
Peningkatan Hasil Belajar Muatan IPA Peserta Didik pada Tema Peduli terhadap Makhluk Hidup Melalui Model Cooperative Learning Tipe CIRC di Kelas IV SDN 216/X Kuala Dendang Semester Ganjil Tahun Ajaran 2021/2022, Murbiatun

\section{Pelaksanaan}

Pelaksanaan kegiatan belajar mengajar untuk siklus I dilaksanakan pada hari Kamis, tanggal 21 Oktober 2021di Kelas IV dengan jumlah peserta didik 8 peserta didik dengan tema yang dibahas Peduli terhadap makhluk Hidup. Dalam hal ini peneliti bertindak sebagai guru. Adapun proses belajar mengajar mengacu pada rencana pelajaran yang telah dipersiapkan yang dilaksanakan dalam tiga kegiatan yaitu kegiatan pendahuluan, kegiatan inti, dan kegiatan penutup. Untuk lebih jelasnya, pelaksanaan pembelajaran diuraikan sebagai berikut.

Pada kegiatan pendahuluan iniGurumemberikan salam dan mengajak semua peserta didikberdo'a menurut agama dan keyakinan masing-masing. Guru mengecek kesiapan diri dengan mengisi lembar kehadiran dan memeriksa kerapihan pakaian, posisi dan tempat duduk disesuaikan dengan kegiatan pembelajaran. Kemudian menginformasikan tema yang akan dibelajarkan yaitu tentang "Peduli Terhadap Makhluk Hidup". Setelah itu, guru menyampaikan tahapan kegiatan yang meliputi kegiatan mengamati, menanya, mengeksplorasi, mengomunikasikan dan menyimpulkan.

Pada kegiatan inti ini Sebagai kegiatan pembuka, guru memperlihatkan serumpun padi kepada peserta didik. Guru mengajukan pertanyaan: Apa yang kalian ketahui tentang tanaman ini?. Setelah itu peserta didik kemudian saling mencocokan jawaban kepada satu/beberapa teman lain. Peserta didik berdiskusi untuk menemukan perbedaan jawaban mereka. Membentuk kelompok yang anggotanya 4 orang peserta didik secara heterogen. Guru memberikan wacana/kliping sesuai dengan topik pembelajaran. Peserta didik bekerja sama saling membacakan dan menemukan ide pokok dan memberi tanggapan terhadap wacana/kliping dan ditulis pada lembar kertas. Peserta didik diminta untuk memilih satu jenis tanaman yang sering mereka konsumsi dalam keseharian. Peserta didik diminta untuk membuat pertanyaan sebanyak mungkin tentang tumbuhan pilihan mereka. Peserta didik diingatkan kembali tentang teks yang telah mereka baca di awal kegiatan pembelajaran. Peserta didik diminta untuk menuliskan tiga tahap pertumbuhan padi, pada diagram yang tersedia. (Mengeksplorasi). Menggunakan diagram tersebut, peserta didik kemudian mendiskusikan bersama teman tentang satu tahapan dari padi yang paling penting untuk dijaga keberadaannya. Peserta didik kemudian membaca informasi tentang jawaban dari permasalahan yang telah mereka diskusikan, yaitu solusi untuk menjaga keberadaan tanaman padi. Peserta didik kembali diminta untuk membuat banyak pertanyaan tentang tumbuhan pilihan mereka. Pertanyaan yang dibuat adalah tentang bagaimana melestarikan tanaman yang dipilih dan mengenai cara-cara menjaga keseimbangan agar tanaman tersebut tidak habis. Setelah itu mempresentasikan/membacakan hasil kelompok. Guru dan peserta didik membuat kesimpulan bersama.

Pada akhir pembelajaran Bersama-sama peserta didik membuat kesimpulan / rangkuman hasil belajar selama sehari. Kemudian bertanya jawab tentang materi yang telah dipelajari (untuk mengetahui hasil ketercapaian materi). Setelah itu guru memberi kesempatan kepada peserta didik untuk menyampaikan pendapatnya tentang pembelajaran yang telah diikuti. Kemudian melakukan 
penilaian hasil belajar. Lalu, mengajak semua peserta didik berdo'a menurut agama dan keyakinan masing-masing (untuk mengakhiri kegiatan pembelajaran).

Pelaksanaan kegiatan belajar mengajar untuk pertemuan dua siklus I dilaksanakan pada Kamis, tanggal 28 Oktober 2021 di Kelas IV denganjumlah peserta didik 8 orang peserta didik tema yang dibahas yaitu mengenai Peduli Terhadap Makhluk Hidup. Dalam hal ini peneliti bertindak sebagai guru.Adapun proses belajarmengajarmengacupadarencanapelajaran yang telahdipersiapkan yang dilaksanakan dalam tiga kegiatan yaitu kegiatan pendahuluan, kegiatan inti, dan kegiatan penutup. Untuk lebih jelasnya, pelaksanaan pembelajaran diuraikan sebagai berikut.

Pada kegiatan pendahuluan ini guru memberikan salam dan mengajak semua peserta didik berdo'a menurut agama dan keyakinan masing-masing. Guru mengecek kesiapan diri dengan mengisi lembar kehadiran dan memeriksa kerapihan pakaian, posisi dan tempat duduk disesuaikan dengan kegiatan pembelajaran. Kemudian menginformasikan tema yang akan dibelajarkan yaitu tentang "Peduli Terhadap Makhluk Hidup". Setelah itu, guru menyampaikan tahapan kegiatan yang meliputi kegiatan mengamati, menanya, mengeksplorasi, mengomunikasikan dan menyimpulkan.

Pada kegiatan inti ini Peserta didik. Peserta didik membentuk kelompok terdiri atas 4 peserta didik tiap kelompok. Peserta didik diingatkan kembali pada pentingnya peran tumbuhan sebagai sumber daya alam hayati. Guru membuka kegiatan dengan memperlihatkan satu jenis tumbuhan yang lengkap dengan bagian-bagiannya: akar, batang, daun, dan buah/bunga. Guru mengajukan pertanyaan: Apa fungsi dari setiap bagian tumbuhan?. Bagian manakah dari tumbuhan yang berfungsi untuk mempertahankan kelestarian tumbuhan tersebut? (biji), peserta didik membaca senyap teks tentang manfaat setiap bagian tumbuhan yang terdapat di buku. Peserta didik kemudian berdiskusi beberapa teman dalam kelompok kecil untuk menjawab pertanyaan tentang bagian tumbuhan lain yang berfungsi untuk mempertahankan kelestarian tumbuhan. Peserta didik membaca teks singkat dan menjawab pertanyaan terkait materi tentang upaya manusia untuk menjaga kelestarian lingkungan. Pengamatan: Setiap peserta didik akan memilih satu tanaman kemudian akan mengamati tanaman tersebut. Peserta didik mengidentifikasi bagian-bagian tumbuhan, fungsi dan menuliskan laporannya. Peserta didik akan mendiskusikan hasil pengamatannya secara berkelompok. Peserta didik menuliskan hasil laporannya di kertas lain. Untuk melengkapi laporannya peserta didik bisa menyertakan gambar. Di akhir kegiatan untuk memahami lebih jauh tentang bagian tumbuhan dan pelestariannya, peserta didik kemudian praktek menanam satu jenis biji di dalam pot. (Mempraktekkan). Kemudian Peserta didik diberikan tanggung jawab untuk merawat tanamannya hingga besar dan berbuah. Kegiatan ini merupakan wujud nyata peserta didik dalam upaya menjaga kelestarian lingkungan.

Pada akhir pembelajaran bersama-sama peserta didik membuat kesimpulan/rangkuman hasil belajar selama sehari. Kemudian bertanya jawab tentang materi yang telah dipelajari (untuk mengetahui hasil ketercapaian materi). Setelah itu guru memberi kesempatan kepada peserta didik untuk menyampaikan pendapatnya tentang pembelajaran yang telah diikuti. Kemudian melakukan 
Peningkatan Hasil Belajar Muatan IPA Peserta Didik pada Tema Peduli terhadap Makhluk Hidup Melalui Model Cooperative Learning Tipe CIRC di Kelas IV SDN 216/X Kuala Dendang Semester Ganjil Tahun Ajaran 2021/2022, Murbiatun

penilaian hasil belajar. Lalu mengajak semua peserta didik berdo'a menurut agama dan keyakinan masing-masing (untuk mengakhiri kegiatan pembelajaran).

\section{Observasi}

Berikut ini adalah deskripsi data hasil pengamatan hasil belajar peserta didik di kelas IV SDN 216/X Kuala Dendang pada siklus I. Adapun data hasil penelitian pada siklus I adalah sebagai berikut:

Tabel 1. Rekapitulasi hasil tes formatif Siklus I

\begin{tabular}{|l|l|l|}
\hline No & Uraian & Hasil \\
\hline 1 & Jumlah Nilai & 510 \\
\hline 2 & Rata-rata Nilai & 63.75 \\
\hline 3 & Peserta didik Tuntas & 5 \\
\hline 4 & Peserta didik Tidak Tuntas & 3 \\
\hline 5 & Persentase Peserta didik Tuntas & $63 \%$ \\
\hline 6 & Persentase Peserta didik Tidak Tuntas & $38 \%$ \\
\hline
\end{tabular}

Dari tabel di atas dapat dijelaskan bahwa dengan menerapkan model pembelajaran CIRC diperoleh nilai rata-rata hasil belajar peserta didik adalah 63,75 dan ketuntasan belajar mencapai $63 \%$ atau ada 5 peserta didik dari 8 peserta didik sudah tuntas belajar. Hasil tersebut menunjukkan bahwa pada siklus pertama secara klasikal peserta didik belum tuntas belajar, karena peserta didik yang memperoleh nilai $\geq 70$ hanya sebesar $63 \%$ lebih kecil dari persentase ketuntasan yang dikehendaki yaitu $80 \%$. Hal ini disebabkan karena peserta didik masih merasa baru dan belum mengerti apa yang dimaksudkan dan digunakan guru dengan menerapkan model pembelajaran CIRC.

\section{Refleksi}

Pada tahap refleksi ini peneliti mengadakan diskusi dengan dibantu oleh seorang observer yang bernama Destri Efrizal, S.Pd. Tahap refleksi diadakan pada hari Senin, tanggal 1 November 2021 bertempat di kantor SDN 216/X Kuala Dendang. Berdasarkan hasil analisis data observasi bersama obsever, dapat disimpulkan refleksi pada siklus I, dengan dua kali pertemuan maka dikemukakan hal-hal sebagai berikut. Hasil belajar peserta didik masih ada yang belum mencapai ketuntasan, dari hasil tes siklus I ada 3 orang peserta didik yang belum mencapai ketuntasan. Ini karena ada beberapa materi yang belum dikuasai oleh beberapa peserta didik. Untuk itu peneliti meminta peserta didik untuk membaca dan mengulangi lagi materi pelajaran di rumah dan meminta peserta didik untuk mencari informasi sebanyak-banyaknya terkait dengan materi yang dipelajari. Dengan demikian pada siklus II diharapkan hasil belajarnya akan lebih meningkat karena materi telah mereka baca dahulu di rumah. Hal lain juga disebabkan bahwa dalam proses belajar mengajar peserta didik masih banyak yang bermain-main atau tidak fokus dalam belajar. Berdasarkan hal tersebut maka peneliti dan observer berusaha untuk menggunakan waktu semaksimal mungkin agar waktu yang disediakan dapat digunakan sebaik mungkin. Kemudian untuk siklus berikutnya guru memberikan tindakan penggantian anggota kelompok. Untuk itu penelitian ini dilanjutkan ke siklus berikutnya. 


\section{Siklus II}

\section{Perencanaan}

Pada tahap ini peneliti mempersiapkan perangkat pembelajaran yang terdiri dari rencana pelajaran 1, LKS 1, bahan ajar, soal tes formatif 1, lembaran observasi dan alat-alat pengajaran yang mendukung.

\section{Pelaksanaan}

Pelaksanaan kegiatan belajar mengajar untuk pertemuan pertama siklus II dilaksanakan pada hari Kamis, 11 November 2021 di Kelas IV dengan jumlah peserta didik 8 orang peserta didik dengan tema Peduli Terhadap Lingkungan. Padahal ini peneliti bertindak sebagai guru.Adapun proses belajar mengajar mengacu pada rencana pelajaran yang telah dipersiapkan yang dilaksanakan dalam tiga kegiatan yaitu kegiatan pendahuluan, kegiatan inti, dan kegiatan penutup. Untuk lebih jelasnya, pelaksanaan pembelajaran diuraikan sebagai berikut.

Pada kegiatan pendahuluan Kelas dibuka dengan salam, menanyakan kabar, dan mengecek kehadiran peserta didik. Kelas dilanjutkan dengan doa dipimpin oleh salah seorang peserta didik. Peserta didik difasilitasi untuk bertanya jawab pentingnya mengawali setiap kegiatan dengan doa. Selain berdoa, guru dapat memberikan penguatan tentang sikap syukur. Peserta didik diajak menyanyikan Lagu Indonesia Raya. Guru memberikan penguatan tentang pentingnya menanamkan semangat kebangsaan. Peserta didik diminta memeriksa kerapian diri dan kebersihan kelas. Peserta didik memperhatikan penjelasan guru tentang tujuan, manfaat, dan aktivitas pembelajaran yang akan dilakukan. Peserta didik menyimak penjelasan guru tentang pentingnya sikap disiplinyang akan dikembangkan dalam pembelajaran. Kemudian pembiasaan membaca. Peserta didik dan guru mendiskusikan perkembangan kegiatan literasi yang telah dilakukan. Peserta didik diajak menyanyikan lagu daerah setempat untuk menyegarkan suasana kembali. Menginformasikan tema yang akan dibelajarkan yaitu tentang "Peduli Terhadap Makhluk Hidup". Guru menyampaikan tahapan kegiatan yang meliputi kegiatan mengamati, menanya, mengeksplorasi, mengomunikasikan dan menyimpulkan.

Pada kegiatan inti ini Guru Peserta didik dibagi dalam kelompok terdiri atas 4 orang tiap kelompok. Kelompok diganti kembali dan berbeda pada pertemuan sebelumnya. guru mengingatkan kembali materi tentang tumbuhan sebagai sumber daya alam hayati yang harus dijaga keberadaannya. Guru memberikan wacana/kliping sesuai dengan topik pembelajaran yaitu hewan di Indonesia yang dilindungi karena hampir punah. Sebagai kegiatan pembuka, guru memperlihatkan gambar hewan di Indonesia yang dilindungi karena hampir punah (Komodo, Badak Bercula Satu). Peserta didik mengamati foto burung Cendrawasih dengan teliti. Peserta didik menuliskan pertanyaan mengenai beragam hal yang ingin mereka ketahui tentang burung tersebut. Peserta didik memberikan pertanyaan yang telah dibuat kepada teman sebangku untuk dijawab. Mereka kemudian saling mendiskusikan jawabanannya. Peserta didik membaca senyap teks tentang burung Cendrawasih untuk melengkapi jawaban yang telah mereka buat. Peserta didik menjawab pertanyaan bacaan tentang 
Peningkatan Hasil Belajar Muatan IPA Peserta Didik pada Tema Peduli terhadap Makhluk Hidup Melalui Model Cooperative Learning Tipe CIRC di Kelas IV SDN 216/X Kuala Dendang Semester Ganjil Tahun Ajaran 2021/2022, Murbiatun

burung Cendrawasih. Peserta didik kemudian memilih satu jenis hewan yang menurut mereka paling menarik. Peserta didik membuat daftar pertanyaan tentang hewan tersebut Daftar pertanyaan harus memuat hal-hal berikut: 1) Tempat tinggal hewan (dataran tinggi, dataran rendah, pantai). 2) Manfaat hewan bagi penduduk setempat khususnya dan bagi rakyat Indonesia umumnya. 3) Upaya-upaya melestarikan dan menjaga keseimbangan hewan sebagai bagian dari sumber daya alam bangsa Indonesia. 4) Ciri-ciri atau bagian hewan dan manfaatnya bagi hewan tersebut. Peserta didik mendiskusikan daftar pertanyaan tersebut bersama guru secara klasikal. Peserta didik membaca teks tentang beragam jenis kupu-kupu. Peserta didik berkreasi membuat poster ajakan untuk menjaga kelestarian satu jenis hewan pilihan yang ada di daerah setempat. Peserta didik disarankan untuk memilih jenis hewan yang dilindungi karena keberadaannya yang mulai langka. Peserta didik bekerja sama saling membacakan dan menemukan ide pokok dan memberi tanggapan terhadap wacana/kliping dan ditulis pada lembar kertas. Kemudian mempresentasikan/membacakan hasil kelompok. Setelah itu guru dan peserta didikmembuatkesimpulanbersama.

Pada kegiatan penutup ini bersama-sama peserta didik membuat kesimpulan/rangkuman hasil belajar selama sehari. Kemudian Bertanya jawab tentang materi yang telah dipelajari (untuk mengetahui hasil ketercapaian materi). Lalu, guru memberi kesempatan kepada peserta didik untuk menyampaikan pendapatnya tentang pembelajaran yang telah diikuti. Melakukan penilaian hasil belajar. Kemudian mengajak semua peserta didik berdo'a menurut agama dan keyakinan masingmasing (untuk mengakhiri kegiatan pembelajaran).

Pelaksanaan kegiatan belajar mengaja runtuk siklus II dilaksanakan pada har iKamis, 18 November 2021 di Kelas IV dengan jumlah pesertadidik 8 orang peserta didik dengan tema Peduli Terhadap Lingkungan, sedangkan dalam hal in ipeneliti bertindak sebagai guru.Adapun proses belajar mengajar mengacu pada rencana pelajaran yang telah dipersiapkan yang dilaksanakan dalam tiga kegiatan yaitu kegiatan pendahuluan, kegiatan inti, dan kegiatan penutup. Untuk lebih jelasnya, pelaksanaan pembelajaran diuraikan sebagai berikut.

Pada kegiatan pendahuluan Kelas dibuka dengan salam, menanyakan kabar, dan mengecek kehadiran peserta didik. Kelas dilanjutkan dengan doa dipimpin oleh salah seorang peserta didik. Peserta didik difasilitasi untuk bertanya jawab pentingnya mengawali setiap kegiatan dengan doa. Selain berdoa, guru dapat memberikan penguatan tentang sikap syukur. Peserta didik diajak menyanyikan Lagu Indonesia Raya. Guru memberikan penguatan tentang pentingnya menanamkan semangat kebangsaan. Peserta didik diminta memeriksa kerapian diri dan kebersihan kelas. Peserta didik memperhatikan penjelasan guru tentang tujuan, manfaat, dan aktivitas pembelajaran yang akan dilakukan. Peserta didik menyimak penjelasan guru tentang pentingnya sikap disiplinyang akan dikembangkan dalam pembelajaran. Kemudian pembiasaan membaca. Peserta didik dan guru mendiskusikan perkembangan kegiatan literasi yang telah dilakukan. Peserta didik diajak menyanyikan lagu daerah setempat untuk menyegarkan suasana kembali. Menginformasikan tema yang akan dibelajarkan yaitu tentang "Peduli Terhadap Makhluk Hidup". Guru menyampaikan 
tahapan kegiatan yang meliputi kegiatan mengamati, menanya, mengeksplorasi, mengomunikasikan dan menyimpulkan.

Pada kegiatan inti ini Guru Peserta didik dibagi dalam kelompok terdiri atas 4 orang tiap kelompok. Kelompok diganti kembali dan berbeda pada pertemuan sebelumnya. Peserta didik diingatkan kembali pada pentingnya peran hewan sebagai sumber daya alam hayati. Guru membuka kegiatan dengan memperlihatkan seekor burung Guru mengajukan pertanyaan: Apa yang kamu ketahui tentang fungsi dari setiap bagian tubuh burung? Peserta didik membaca senyap teks singkat tentang seorang anak yang menolong seekor burung yang terluka. Peserta didik kemudian mengidentifikasi setiap bagian dari tubuh burung, kemudian menuliskannya bagian-bagian tersebut beserta fungsinya di tabel yang tersedia. Peserta didik kemudian mengerjakan satu soal pemecahan masalah, jika dihadapkan pada situasi yang sama dengan tokoh yang ada dalam buku, yaitu melihat burung yang terluka. Peserta didik mengamati bagian tubuh laba-laba dan kumbang. Peserta didik kemudian mengidentifikasi perbedaan dari laba-laba dan kumbang beserta fungsinya dalam pelestarian lingkungan. Peserta didik kembali diminta membuat pertanyaan tentang fungsi bagian hewan. Peserta didik menuliskan pertanyan tambahan tersebut pada daftar pertanyaan mereka diawal kegiatan. Peserta didik bekerja sama saling membacakan dan menemukan ide pokok dan memberi tanggapan terhadap wacana/kliping dan ditulis pada lembar kertas. Kemudian mempresentasikan /membacakan hasil kelompok. Setelah itu guru dan peserta didik membuat kesimpulan bersama.

Pada kegiatan penutup ini bersama-sama peserta didik membuat kesimpulan/rangkuman hasil belajar selama sehari. Kemudian Bertanya jawab tentang materi yang telah dipelajari (untuk mengetahui hasil ketercapaian materi). Lalu, guru memberi kesempatan kepada peserta didik untuk menyampaikan pendapatnya tentang pembelajaran yang telah diikuti. Melakukan penilaian hasil belajar. Kemudian mengajak semua peserta didik berdo'a menurut agama dan keyakinan masingmasing (untuk mengakhiri kegiatan pembelajaran).

\section{Observasi}

Pengamatan (observasi) dilaksanakan bersamaan dengan pelaksanaan belajar mengajar. Berikutnya adalah rekapitulasi hasil tes formatif peserta didik terlihat pada tabel berikut.

Tabel 2. Rekapitulasi hasil tes formatif Siklus II

\begin{tabular}{|c|c|c|}
\hline No & Uraian & Hasil \\
\hline 1 & Jumlah Nilai & 620 \\
\hline 2 & Rata-rata Nilai & 77.50 \\
\hline 3 & Peserta didik Tuntas & 7 \\
\hline 4 & Peserta didik Tidak Tuntas & 1 \\
\hline 5 & Persentase Peserta didik Tuntas & $88 \%$ \\
\hline 6 & Persentase Peserta didik Tidak Tuntas & $13 \%$ \\
\hline
\end{tabular}

Dari tabel di atas diperoleh nilai rata-rata hasil belajar peserta didik adalah 77,50 dan ketuntasan belajar mencapai $88 \%$ atau ada 7 peserta didik dari 8 peserta didik sudah tuntas belajar. Sedangkan 1 orang dari 8 orang peserta didik lagi atau 13\% tidak tuntas belajar Hasil ini 
Peningkatan Hasil Belajar Muatan IPA Peserta Didik pada Tema Peduli terhadap Makhluk Hidup Melalui Model Cooperative Learning Tipe CIRC di Kelas IV SDN 216/X Kuala Dendang Semester Ganjil Tahun Ajaran 2021/2022, Murbiatun

menunjukkan bahwa pada siklus II ini ketuntasan belajar secara klasikal telah mengalami peningkatan sedikit lebih baik dari siklus I. kemudian target ketuntasan yang dikehendaki sudah tercapai dan telah lebih dari $80 \%$.

\section{Refleksi}

Tahap refleksi siklus II dilaksanakan pada hari senin, tanggal 22 November 2021 pada jam 11.30 sampai 13.30 dengan dibantu oleh seorang observer yang bernama Destri Efrizal, S.Pd. yang bertempat di ruangan majelis guru. Dalan diskusi ini guru dan observer menjelaskan bahwa adanya peningkatan hasil belajar peserta didik ini karena setelah guru memberikan tindakan pergantian anggota kelompok. Sehingga pada pertemuan berikutnya peserta didik lebih termotivasi untuk belajar. Selain itu peserta didik juga sudah mulai mengerti apa yang dimaksudkan dan dinginkan guru dengan menerapkan model pembelajaran CIRC. Oleh karena itu penelitian ini tidak dilanjutkan ke siklus berikutnya.

\section{Diskusi}

Dalam pembelajaran dengan model pembelajaran CIRC ini peserta didik diarahkan menemukan konsep dengan bantuan membaca buku melalui kegiatan-kegiatan kelompok. Dalam pembelajaran, guru membimbing peserta didik berada disamping mereka yang membutuhkan bimbingan, membuat peserta didik merasa puas dan senang dan merasa diperhatikan sehingga peserta didik merasa bersemangat belajar. Pelaksanaan model CIRC di kelas IV SDN 216/X Kuala Dendang telah memberikan dampak yang positif, hal ini ditandai dengan peningkatan hasil belajar peserta didik pada siklus I dan siklus II yaitu dari $63 \%$ menjadi $88 \%$.

Pada hakikatnya hasil belajar merupakan bagian terpenting dalam pembelajaran. Nana Sudjana (2009:3) mendefinisikan hasil belajar peserta didik pada hakikatnya adalah perubahan tingkah laku sebagai hasil belajar dalam pengertian yang lebih luas mencakup bidang kognitif, afektif, dan psikomotorik. Sejalan dengan itu Dimyati dan Mudjiono (2006:3-4) juga menyebutkan hasil belajar merupakan hasil dari suatu interaksi tindak belajar dan tindak mengajar. Dari sisi guru, tindak mengajar diakhiri dengan proses evaluasi hasil belajar.

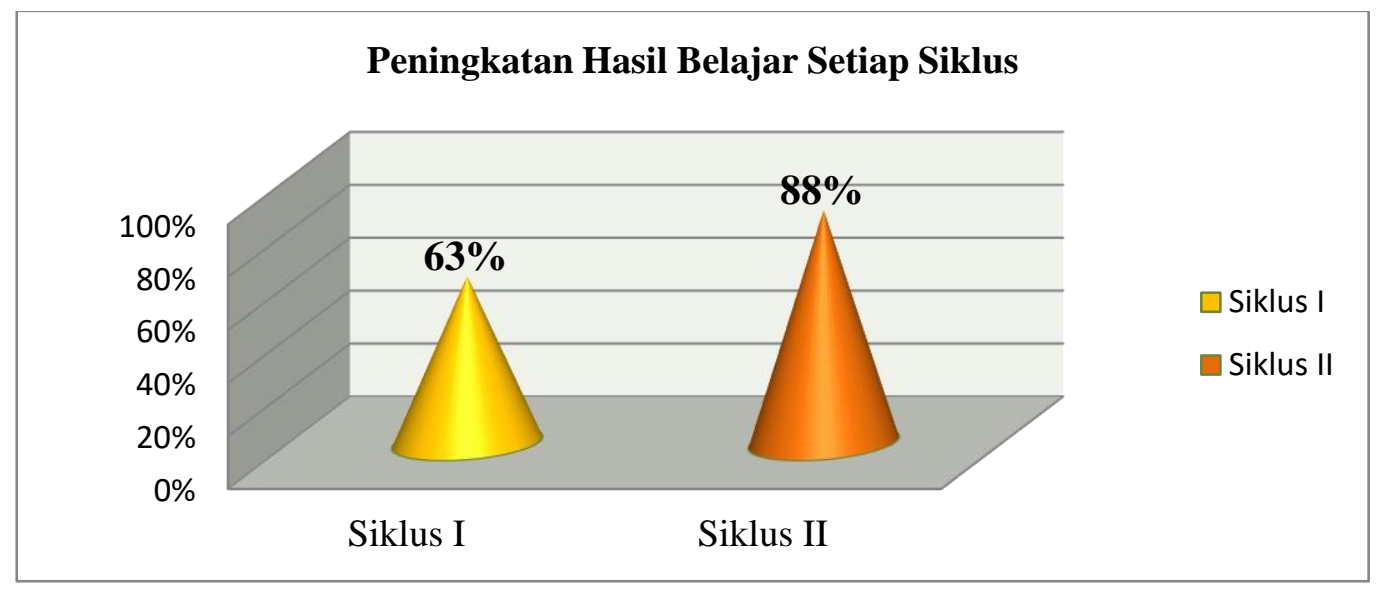

Gambar 1. Grafik Peningkatan Setiap Siklus 


\section{KESIMPULAN}

Berdasarkan hasil kegiatan pembelajaran yang telah dilakukan selama dua siklus, dan berdasarkan seluruh pembahasan serta analisis yang telah dilakukan dapat disimpulkan sebagai berikut: model pembelajaran CIRC memiliki dampak positif dalam meningkatkan hasil belajar peserta didik. Hal ini dapat dilihat dari semakin mantapnya pemahaman peserta didik terhadap materi yang disampaikan guru (ketuntasan belajar meningkat dari sklus I, sampai II yaitu masing-masing siklus I 3\%, dan siklus II 88\%, Pada siklus II ketuntasan belajar peserta didik secara klasikal telah tercapai dengan tindakan penggantian anggota kelompok.

Dari hasil penelitian yang diperoleh dari uraian sebelumnya agar proses belajar pembelajaran muatan IPA lebih efektif dan lebih memberikan hasil yang optimal bagi peserta didik, maka disampaikan saran yaitu untuk melaksanakan model pembelajaran CIRC memerlukan persiapan yang cukup matang, sehingga guru harus mampu menentukan atau memilih topik yang benar-benar bisa diterapkan dengan model pembelajaran CIRC dalam proses belajar mengajar sehingga diperoleh hasil yang optimal. Kemudian dalam rangka meningkatkan hasil belajar peserta didik, guru hendaknya lebih sering melatih peserta didik dengan berbagai model pengajaran, walau dalam taraf yang sederhana, dimana peserta didik nantinya dapat menemukan pengetahuan baru, memperoleh konsep dan keterampilan, sehingga peserta didik berhasil atau mampu memecahkan masalah-masalah yang dihadapinya. Selain itu, perlu adanya penelitian yang lebih lanjut, karena hasil penelitian ini hanya dilakukan di SDN 216/X Kuala Dendang semester ganjil tahun ajaran 2021/2022. Lalu, untuk penelitian yang serupa hendaknya dilakukan perbaikan-perbaikan agar diperoleh hasil yang lebih baik.

\section{REFERENSI}

Agus suprijono. 2010. Cooperative Learning. Yogyakarta. Pustaka Media.

Agus Supriyono. 2009. Cooperative Learning. Yogyakarta: Pustaka Pelajar.

Ahmad, Susanto. (2013). Teori Belajar dan Pembelajaran di Seklah Dasar. Jakarta: Kencana Prenada Media Group.

Amin Suyitno. 2005. Mengadopsi Pembelajaran CIRC dalam meningkatkanKeterampilan Peserta didik Menyelesaikan Soal Cerita. Seminar NasionalF.MIPA UNNES. (online)

Arsyad, Azhar. 2011. Media Pembelajaran. Jakarta: PT. Raja Grafindo Persada.

Dimyati dan Mudjiono. 2006. Belajar dan Pembelajaran. Jakarta: PT Rineke. Cipta.

Dimyati, dan Mudjiono, (2013), Belajar dan Pembelajaran, Rineka Cipta. Jakarta

Istarani. 2011. 58 Model Pembelajaran Inovatif. Medan: CV.ISCOM Medan.

Moh. Surya. (1981). Pengantar Psikologi Pendidikan. Bandung: FIP IKIP Bandung.

Mulyasa. 2006. Kurikulum yang di sempurnakan. Bandung: PT Remaja. Rosdakarya.

Sudjana, Nana .2009. Penilaian Hasil Proses Belajar Mengajar. Bandung: PT. Remaja Rosdakarya.

Ngalimun. 2012. Strategi dan Model Pembelajaran. Banjarmasin: AswajaPregssindo.

Ngalimun. 2012. Strategi dan Model Pembelajaran. Yogyakarta: Aswaja Pressindo. 
Peningkatan Hasil Belajar Muatan IPA Peserta Didik pada Tema Peduli terhadap Makhluk Hidup Melalui Model Cooperative Learning Tipe CIRC di Kelas IV SDN 216/X Kuala Dendang Semester Ganjil Tahun Ajaran 2021/2022, Murbiatun

Samatowa, Usman. (2006). Bagaimana Membelajarkan IPA Di Sekolah Dasar. Jakarta: Depdiknas.

Slavin, Robert E. 2005. Cooperative Learning: Theory, Research a Practice (N. Yusron. Terjemahan). London: AllymandBacon. Buku asli diterbitkan tahun 2005

Slavin, Robert. E. 2010. Cooperative Learning Teori, Riset dan Praktik. Bandung: Nusa Media. Umardi Suryabrata. (1984). Psikologi Pendidikan. Jakarta: Rajawali Pers. 